\title{
Different rates of tramadol infusion for peri and postoperative analgesia in dogs undergoing orthopedic surgery
}

\author{
[Comparação de diferentes taxas de infusão de tramadol para analgesia peri e pós-operatória \\ em cães submetidos a procedimentos cirúrgicos ortopédicos sob anestesia geral inalatória]

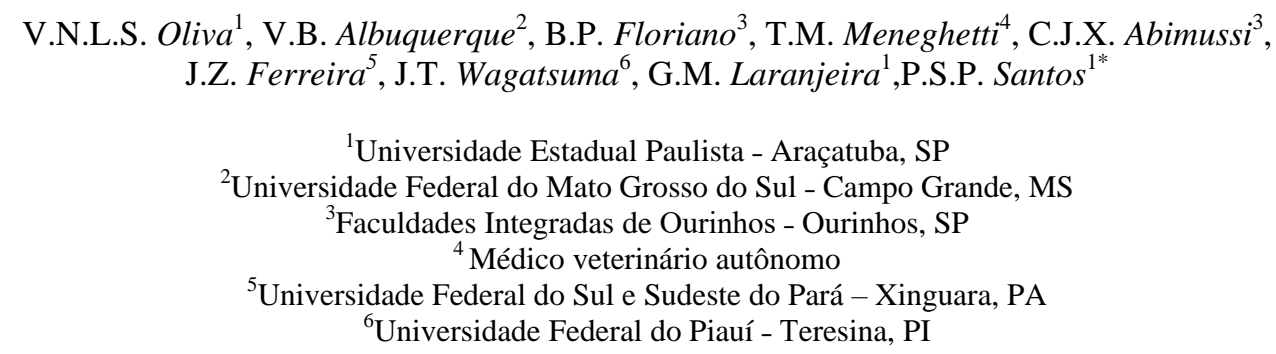

\begin{abstract}
The study aimed to determine the continuous rate infusion of tramadol associated with peri- and postoperative analgesia for orthopedic surgeries in dogs, as well as cardiorespiratory and adverse effects. Thirty dogs aged $4.2 \pm 1.2$ years and weighing $15.1 \pm 0.9 \mathrm{~kg}$ were enrolled in the study, premedicated intramuscularly with acepromazine $\left(0.04 \mathrm{mg} \mathrm{kg}^{-1}\right)$ and tramadol $\left(2 \mathrm{mg} \mathrm{kg}^{-1}\right)$; anesthesia was induced with propofol and maintained with isoflurane in oxygen. Three infusion rates were compared, comprising three experimental groups: G2: 2.0mg kg ${ }^{-1} \mathrm{~h}^{-1}$; G2.5: $2.5 \mathrm{mg} \mathrm{kg}^{-1} \mathrm{~h}^{-1}$; and G3: $3.0 \mathrm{mg} \mathrm{kg}^{-1} \mathrm{~h}^{-1}$. Surgery was initiated 15 minutes following the start of tramadol infusion. During anesthesia, animals were monitored in predefined time points: immediately after tracheal intubation and start of inhalation anesthesia (T0); surgical incision (TSI); final suture (TFS) and end of tramadol infusion (TEI), which was maintained for at least 120 minutes and prolonged according to the duration of surgery. Postoperative analgesia was evaluated through an interval pain scoring scale and the Melbourne pain scale. The mean time of tramadol infusion was greater than 120 minutes in all groups and no differences were found among them (141 \pm 27 minutes in G2, 137 \pm 27 minutes in G2.5 and $137 \pm 30$ minutes in G3). Perioperative analgesia was regarded as short and did not correlate with infusion rates. Tramadol infusion provided adequate analgesia with cardiorespiratory stability Analgesia was not dose-dependent, however, and residual postoperative effects were short-lasting, which warrants proper postoperative analgesia following tramadol infusion. Additional studies are required using higher infusion rates and standardized nociceptive stimulation in order to determine how doses influence tramadol analgesia and whe therthereis a limit to its effect in dogs.
\end{abstract}

Keywords: dogs, orthopedics, analgesia, opioid

\section{RESUMO}

Objetivou-se determinar a infusão de taxa contínua de tramadol associada à analgesia peri e pós-operatória para cirurgias ortopédicas em cães, além de efeitos cardiorrespiratórios e adversos. Foram utilizados 30 cães,

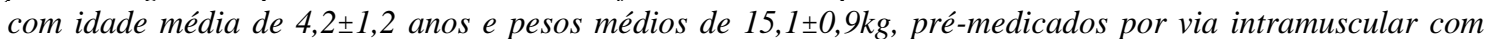
acepromazina $(0,04 \mathrm{mg} / \mathrm{kg})$ e tramadol $(2 \mathrm{mg} / \mathrm{kg})$. A anestesia foi induzida com propofol e mantida com isoflurano em oxigênio. Foram comparadas três taxas de infusão, compreendendo três grupos experimentais: G2: 2,Omg/kg; G2,5: 2,5mg/ $\mathrm{kg}^{l}$; e G3: 3,0mg/kg. A cirurgia começou 15 minutos após o início da infusão de tramadol. Durante a anestesia, os animais foram monitorados nos seguintes momentos: imediatamente após a intubação traqueal e o início da anestesia inalatória (TO); incisão cirúrgica (TSI); final de sutura (TFS) e final da infusão de tramadol (TEI), que foi mantida por, pelo menos, 120 minutos e prolongada de acordo com a duração da cirurgia. A analgesia pós-operatória foi avaliada por escalas de pontuação de dor, conforme a

Recebido em 15 de agosto de 2017

Aceito em 22 de maio de 2018

*Autor para correspondência (corresponding author)

E-mail: vevebat@yahoo.com.br 
escala intervalar de avaliação de dor e a escala de contagem variável de avaliação de dor da Universidade de Melbourne, a cada uma hora. O tempo médio de infusão de tramadol foi maior que 120 minutos em todos os

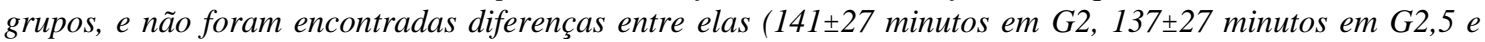
$137 \pm 30$ minutos em G3). A analgesia perioperatória foi adequada na maioria dos indivíduos e a pósoperatória foi considerada curta, não correlacionada àquelas com diferentes taxas de infusão. A infusão de tramadol nas taxas estudadas produziu analgesia adequada com estabilidade cardiorrespiratória. A analgesia não foi dose dependente, no entanto os efeitos residuais pós-operatórios foram considerados curtos, o que determina a necessidade de analgesia adequada após infusão contínua de tramadol. Estudos adicionais que utilizam taxas mais elevadas de infusão de tramadol e estimulação nociceptiva padrão são necessários para determinar em que medida as doses influenciam a analgesia de tramadol e se há um limite nos seus efeitos nos cães.

Palavras-chave: cães, ortopedia, analgesia, opioide

\section{INTRODUCTION}

In the last decade, pain management has become a major concern in animal healthcare, especially in small companion animals. Pathophysiological responses are initiated with pain and comprise cardiovascular, metabolic and neuroendocrine events that contribute to slower healing processes and cause behavioral changes (Kissin, 2000; Vadivelu et al., 2014). Proper recognition and treatment of pain is therefore crucial (Karrasch et al., 2015), along with ethical and humane issues regarding pain management in animals. Clinical assessment of pain poses a challenge in animals due to the subjectivity, complexity and multidimensionality of the experience of pain (Paolozzi et al., 2011).

Tramadol is an opioid analgesic of central action (Ide et al., 2006) that has gained attention in veterinary anesthesia and analgesia due to its distinct mechanism of action, associated with less adverse effects compared to other opioids (Mastrocinque and Fantoni, 2003). Tramadol is commercialized as a racemic mixture (1:1) containing two enantiomers. It is metabolized in the liver to M1 (O-desmethyltramadol), which has a 200-time greater affinity for mu receptors compared to the original molecule (Kukanich and Papich, 2004). This metabolite also provides analgesia through inhibition of serotonin and epinephrine reuptake in the spinal cord (Karrasch et al., 2015).

In view of all these mechanisms, tramadol has been indicated for management of moderate to severe pain and has been successfully used for peri- and postoperative analgesia of dogs subjected to orthopedic surgery (Yazbek and Fantoni, 2005; Vettorato et al., 2010). Tramadol also produces significant reduction on minimal alveolar concentration (MAC) of volatile agents in dogs when used through constant rate infusion (CRI) (Seddigh et al., 2009, Mahidol et al., 2015).

This study is justified by the growing importance of pain management in animals and by the safety of tramadol as an effective analgesic with minimal adverse effects in dogs. In addition, studies regarding the use of tramadol by CRI are still scarce and, therefore, the primary objective of this study was to determine the rate of tramadol infusion associated with peri- and postoperative analgesia in dogs subjected to orthopedic surgery. The secondary aim was to determine cardiorespiratory and adverse effects the use of tramadol. Plasma concentrations of cortisol, blood glucose and blood gas variables were also assessed during tramadol infusion. The main hypothesis of the study was that tramadol infusion would suffice to maintain adequate analgesia during orthopedic procedures in dogs.

\section{MATERIALS AND METHODS}

The study followed the guidelines of CONCEA (National Council for Animal Experimentation Control), and the experimental procedure was approved by the Institutional Animal Care Committee (protocol no. 00476/2011).

Thirty dogs from the clinical care service of the institution's veterinary hospital were enrolled in the study. Dogs presented various orthopedic conditions, including long bone fractures, cranial cruciate ligament rupture, patellar luxation and hip dislocation. 
Criteria for inclusion in the study were normal results on physical examination (heart rate, systolic blood pressure, respiratory rate, mucosal coloration, capillary refill time and rectal temperature), complete blood count, hepatic (alanine transaminase and alkaline phosphatase) and renal function (creatinine and urea nitrogen) and negative Leishmaniasis test (endemic region). Exclusion criteria comprised any changes on clinical tests. Animals that received previous treatment with tramadol were suspended from medications the day before each procedure. Animals were equally distributed among groups in order to achieve homogeneity of different surgeries in each group.

Prior to general anesthesia, animals were fasted for 12 hours and water was withheld for 2 hours. Baseline variables included heart rate (HR, beats minute $\left.{ }^{-1}\right)$, respiratory rate $\left(F_{\mathrm{R}}\right.$, movement's minute $^{-1}$ ), systolic arterial blood pressure (SABP, $\mathrm{mmHg}$ ) and rectal temperature (RT, ${ }^{\circ} \mathrm{C}$ ). Premedication was given intramuscularly and comprised acepromazine (Acepran 1\%; Acepromazine 1\%; Univet, Brazil) at $0.04 \mathrm{mg} \mathrm{kg}$ ${ }^{1}$, in combination with tramadol (Tramadon $50 \mathrm{mg} \mathrm{mL}^{-1}$; Tramadol 50mg $\mathrm{mL}^{-1}$; Cristália chemicals and pharmaceuticals Ltda., Brazil) at $2 \mathrm{mg} \mathrm{kg}^{-1}$.

Following 20 minutes of premedication, the cephalic vein was aseptically catheterized for fluid administration (Lactated Ringer's Solution; Medical Line, Brazil) at $10 \mathrm{~mL} \mathrm{~kg}^{-1} \mathrm{~h}^{-1}$ and for induction to anesthesia with propofol (Propovan $10 \mathrm{mg} \mathrm{mL}^{-1}$; Propofol 10mg $\mathrm{mL}^{-1}$;Cristália chemicals and pharmaceuticals Ltda., Brazil) at $3 \mathrm{mg} \mathrm{kg}^{-1}$ and midazolam (Dormire $5 \mathrm{mg} \mathrm{mL}^{-1}$; Midazolam $5 \mathrm{mg} \mathrm{mL}^{-1}$;Cristália chemicals and pharmaceuticals Ltda., Brazil) at $0.2 \mathrm{mg} \mathrm{kg}^{-1}$.

Intubation was carried out immediately after induction and the tracheal tube was coupled to a rebreathing circle system. Anesthesia was maintained with isoflurane (Isoforine; Isoflurane; Cristália chemicals and pharmaceuticals Ltda., Brazil) at variable concentrations depending on individual requirements for surgical anesthesia. End-tidal isoflurane (ET ${ }_{\text {ISO }}$ ) was monitored throughout the surgery by a gas analyzer calibrated before each procedure using a standard gas sample (Quick CalTM calibration gas; Datex-Engstrom Division Instrumentarium Corp; Finland). Following instrumentation, the contralateral cephalic vein was catheterized for tramadol infusion, which was started after a $2 \mathrm{mg}$ $\mathrm{kg}^{-1}$ bolus and comprised different rates, or three groups: (G2) $2 \mathrm{mg} \mathrm{kg}^{-1} \mathrm{~h}^{-1}$; (G2.5) $2.5 \mathrm{mg} \mathrm{kg}^{-1} \mathrm{~h}^{-1}$; and (G3) $3 \mathrm{mg} \mathrm{kg}^{-1} \mathrm{~h}^{-1}$. Surgery was initiated 15 minutes following the start of CRI.

During anesthesia, animals were monitored at predefined time points: immediately after tracheal intubation and start of inhalation anesthesia (T0); surgical incision (TSI); final suture (TFS) and end of tramadol infusion (TEI), which was maintained for at least 120 minutes and prolonged according to the duration of surgery. In addition, other time points were defined as important moments of nociceptive stimulation, such as manipulation of the periosteum or joint (T1) and any other (T2) according to the type of surgery: (1) femur head resections comprised the use of an osteotome to remove the head of the femur and osseous incongruences; (2) osteosyntheses using external fixation or intramedullary pin comprised the use of a gauge or a bone clamp and periosteum perforation with an electric drill; (3) knee surgeries for cranial cruciate ligament rupture comprised trochlear groove deepening and periosteum perforation.

Data collection comprised the following variables: electrocardiography (ECG; Digital Electrocardiograph; TEB; Brazil), $\mathrm{HR}, F_{\mathrm{R}}$, esophageal temperature (ET), non-invasive systolic, mean and diastolic arterial blood pressures (SABP, DABP and MABP, respectively), end-tidal carbon dioxide tension $\left(\mathrm{ET}^{\prime} \mathrm{CO}_{2}\right)$, oxyhemoglobin saturation $\left(\mathrm{SpO}_{2}\right)$ and $\mathrm{ET}^{\prime}$ Iso. Venous blood samples were obtained from the jugular vein into lithium heparin syringes for blood lactate measurements using a portable device (Accutrend lactate; Roche Diagnostic Brazil Ltda., Brazil), for tramadol and O-desmethyl tramadol dosing through high performance liquid chromatography (HPLC) and for serum cortisol dosing through chemiluminescence. Blood lactate was measured at baseline and at all time points during general anesthesia, whereas tramadol and M1 were continuously dosed at 30-minute intervals following the end of suture until rescue analgesia was required. Serum cortisol was dosed at all time points and every hour following the end of suture until the administration of rescue analgesia as well. 
Blood gas analyses were performed on venous blood samples obtained at TSI, T1, T2, TFS and TEI for assessment of arterial oxygen tension $\left(\mathrm{PaO}_{2}\right)$, arterial carbon dioxide tension $\left(\mathrm{PaCO}_{2}\right)$, base excess (BE), bicarbonate, glucose and electrolytes $\left(\mathrm{Na}^{+}, \mathrm{K}^{+}, \mathrm{iCa}^{2+}\right.$, and $\left.\mathrm{Cl}^{-}\right)$. Analyses were performed immediately after blood sampling using a portable analyzer (i-Stat, Abbott, Brazil).

Animals were positioned over electrical pads in order to maintain body temperature above $36.5^{\circ} \mathrm{C}$ and recumbency was determined by the type of surgery. If signs of nociception were detected throughout the surgery $(20 \%$ increase in $\mathrm{HR}, F_{\mathrm{R}}$ or ABP compared to measurements taken before surgical incision - baseline), fentanyl (Fentanest $0,05 \mathrm{mg} / \mathrm{mL}^{-1}$; Fentanyl $0,05 \mathrm{mg} / \mathrm{mL}^{-1}$; Cristália chemicals and pharmaceuticals Ltda., Brazil) was given intravenously at $2,5 \mu \mathrm{g} \mathrm{kg}^{-1}$ followed by a CRI at $5 \mu \mathrm{g} \mathrm{kg}^{-1} \mathrm{~h}^{-1}$ until the end of surgery.

Postoperative evaluations were only performed on subjects who underwent tramadol CRI without need for fentanyl analgesia. Pain assessment was initiated immediately after subjects regained conscience from anesthesia and every 30 minutes (T30, T60, T90... Tn) until pain scores were reached for rescue analgesia: 3.0 for the Glasgow composite pain scale (Morton et al., 2005) and 8.0 for the Melbourne pain scale (Firth e Haldane, 1999). Rescue analgesia comprised subcutaneous injection of meloxicam (Bioflac $5 \mathrm{mg} / \mathrm{mL}^{-1}$; Meloxicam 5mg/mL $\mathrm{mL}^{-1 ;}$ Cristália chemicals and pharmaceuticals Ltda., Brazil) at $0.2 \mathrm{mg} \mathrm{kg}^{-1}$ and intravenous morphine (Dimorf $10 \mathrm{mg} / \mathrm{mL}^{-1}$; morphine $10 \mathrm{mg} / \mathrm{mL}^{-1}$;Cristália chemicals and pharmaceuticals Ltda., Brazil) at $0.1 \mathrm{mg} \mathrm{kg}^{-1}$, followed by epidural injection of $0.1 \mathrm{mg} \mathrm{kg}^{-1}$ morphine in saline solution at $0.3 \mathrm{~mL} \mathrm{~kg}$. Effective analgesia was defined as no requirement for additional analgesia.

Data were subjected to analysis of variance for repeated measures and mean comparisons were performed using Tukey's test. The respiratory rate was analyzed using Kruskal-Wallis' test for group comparisons and Friedman's test for time point comparisons, followed by Dunn's post-hoc test.

Variable associations were tested using chisquare test of Fisher's exact test. Time to rescue analgesia and pain scores were analyzed using Kruskal-Wallis' test for group comparisons. Statistical significance was considered when $\mathrm{P}<$ 0.05 and analyses were performed by SAS (Statistical Analysis System).

\section{RESULTS}

The mean age and body weight of the subjects included in G2, G2.5 and G3 were5.3 \pm 3.6 , $4.4 \pm 2.9$ and $2.9 \pm 1.3$ years and 14.1 \pm 9.6 , $15.2 \pm 14.1$ and $15.9 \pm 11.1 \mathrm{~kg}$, respectively. Thetype of surgery and time (morning/afternoon) were homogenously distributed in all groups $(\mathrm{P}=$ 1.0000) (Tab. 1). The duration of surgery was slightly shorter in G2.5 (76 \pm 26 minutes), although no differences were found among groups (G2: $95 \pm 31$ minutes and G3: $85 \pm 47$ minutes).

The total time of infusion prior to the start of surgery, which was determined to be at least 15 minutes, was $40 \pm 16,39 \pm 15$ and $39 \pm 7$ minutes in G2, G2.5 and G3, respectively. During this time, patients were correctly positioned and the surgical team prepared for surgery.

The mean time of tramadol infusion was greater than 120 minutes in all groups and no differences were found among them $(141 \pm 27$ minutes in $G 2$, $137 \pm 27$ minutes in $\mathrm{G} 2.5$ and $137 \pm 30$ minutes in G3).

With regard to perioperative evaluations, HR, $F_{\mathrm{R}}, \mathrm{SpO}_{2}, \mathrm{SABP}, \mathrm{MABP}$ and DABP did not differ among groups. Electrocardiography showed no relevant changes throughout the study in all groups. Mean RT dropped compared to baseline RT, reaching a minimum mean value of $35.7 \pm 0.9^{\circ} \mathrm{C}$ in $\mathrm{G} 3$.

Blood lactate did not differ among groups, although means decreased significantly over time compared to baseline in all three groups, with $1.8 \pm 0.8 \mathrm{mmol} \mathrm{L}^{-1}$ in $\mathrm{G} 2 ; 1.7 \pm 0.7 \mathrm{mmol} \mathrm{L}^{-1}$ in $\mathrm{G} 2.5$ and $1.5 \pm 0.5 \mathrm{mmol} \mathrm{L}^{-1}$ in G3 at TFS. Serum cortisol and blood glucose did not differ among groups and a significant increase was observed over time compared to baseline (Table 2). Tramadol and M1 differed between G2.5 and G3 and peak plasma concentrations were reached at TFS. Both variables increased over time during surgery compared to the initial values at TSI (Table 3). 
Different rates...

Table 1. Type of surgery performed in each subject inside each group

\begin{tabular}{ccc}
\hline Animal & Group & Procedure \\
\hline Animal 1 & G2.5 & Femur head resection \\
Animal 2 & G2.0 & Intramedullary pin \\
Animal 3 & G3.0 & Knee surgery* \\
Animal 4 & G2.5 & External fixation \\
Animal 5 & G3.0 & Femur head resection \\
Animal 6 & G2.0 & Femur head resection \\
Animal 7 & G2.5 & Intramedullary pin \\
Animal 8 & G3.0 & External fixation \\
Animal 9 & G2.0 & Femur head resection \\
Animal 10 & G3.0 & External fixation \\
Animal 11 & G2.5 & Femur head resection \\
Animal 12 & G2.0 & Intramedullary pin \\
Animal 13 & G2.0 & External fixation \\
Animal 14 & G3.0 & Intramedullary pin \\
Animal 15 & G2.5 & Intramedullary pin \\
Animal 16 & G2.0 & Knee surgery* \\
Animal 17 & G3.0 & Intramedullary pin \\
Animal 18 & G2.5 & External fixation \\
Animal 19 & G3.0 & Femur head resection \\
Animal 20 & G2.5 & External fixation \\
Animal 21 & G2.0 & Knee surgery* \\
Animal 22 & G2.0 & Knee surgery* \\
Animal 23 & G2.5 & Knee surgery* \\
Animal 24 & G3.0 & Femur head resection \\
Animal 25 & G3.0 & Knee surgery* \\
Animal 26 & G2.0 & Femur head resection \\
Animal 27 & G2.5 & Knee surgery* \\
Animal 28 & G2.5 & Intramedullary pin \\
Animal 29 & G3.0 & Knee surgery* \\
Animal 30 & G2.0 & External fixation \\
\hline
\end{tabular}

*Knee surgery: cranial cruciate ligament rupture, which comprised deepening of the trochlear groove and periosteum perforation.

Table 2. Mean ( $\mathrm{X}) \pm$ standard deviation (S) of blood glucose $\left(\mathrm{mg} \mathrm{dL}^{-1}\right)$ and serum cortisol (ng dL ${ }^{-1}$ ) of dogs subjected totramadol infusion at 2 (G2), 2.5 (G2.5) or 3 (G3) $\mathrm{mg} \mathrm{kg}^{-1} \mathrm{~h}^{-1}$

\begin{tabular}{ccccccc}
\hline \multirow{2}{*}{ Time point } & \multicolumn{3}{c}{ Blood glucose $(\mathrm{X} \pm \mathrm{S})$} & \multicolumn{3}{c}{ Serum cortisol $(\mathrm{X} \pm \mathrm{S})$} \\
\cline { 2 - 7 } & $\mathrm{G} 2$ & $\mathrm{G} 2.5$ & $\mathrm{G} 3$ & $\mathrm{G} 2$ & $\mathrm{G} 2.5$ & $\mathrm{G} 3$ \\
\hline Baseline & $96 \pm 11$ & $93 \pm 10$ & $97 \pm 20$ & $3.76 \pm 1.67$ & $4.28 \pm 3.36$ & $4.08 \pm 2.04$ \\
TSI & $107 \pm 17$ & $93 \pm 9$ & $99 \pm 28$ & $2.58 \pm 2.31$ & $2.56 \pm 1.19$ & $2.58 \pm 2.29$ \\
T1 & $133 \pm 26^{*}$ & $116 \pm 25^{*}$ & $111 \pm 27$ & $6.97 \pm 4.10^{*}$ & $5.72 \pm 3.31^{\dagger}$ & $6.00 \pm 3.02^{\dagger}$ \\
T2 & $133 \pm 26^{*}$ & $112 \pm 31^{*}$ & $114 \pm 30^{*}$ & $8.29 \pm 3.55^{*}$ & $7.06 \pm 3.66^{\dagger}$ & $6.78 \pm 2.84^{\dagger}$ \\
TFS & $129 \pm 28^{*}$ & $112 \pm 24^{*}$ & $105 \pm 20$ & $6.79 \pm 1.91^{*}$ & $8.25 \pm 4.77^{* \dagger}$ & $6.18 \pm 3.24^{\dagger}$ \\
TEI & $129 \pm 28^{*}$ & $110 \pm 24$ & $102 \pm 21$ & $6.99 \pm 2.30^{*}$ & $8.73 \pm 5.45^{* \dagger}$ & $5.34 \pm 2.16^{\dagger}$ \\
\hline
\end{tabular}

$\mathrm{G} 2=\mathrm{G} 2.5=\mathrm{G} 3$. *Differs from baseline according to Tukey test $(\mathrm{P}<0.05) .^{\dagger}$ Differs from TSI according to Tukey test $(\mathrm{P}<0.05)$. Serum cortisol transformed to $\log$.

TSI - surgical incision, T1 - manipulation of the periosteum or joint, T2 - important times of nociceptive stimulation,TFS - final suture and TEI - end of tramadol infusion. 
Table 3. Mean $(\mathrm{X}) \pm$ standard deviation (S) of plasma tramadol $\left(\mu \mathrm{g} \mathrm{mL} L^{-1}\right)$ and $\mathrm{M} 1\left(\mathrm{ng} \mathrm{mL} L^{-1}\right)$ of $\operatorname{dogs}$ subjected to tramadol infusion at $2(\mathrm{G} 2), 2.5(\mathrm{G} 2.5)$ or $3(\mathrm{G} 3) \mathrm{mg} \mathrm{kg}^{-1} \mathrm{~h}^{-1}$

\begin{tabular}{cccc}
\hline \multirow{2}{*}{ Time point } & \multicolumn{3}{c}{ Plasma tramadol $(\mathrm{X} \pm \mathrm{S})$} \\
\cline { 2 - 4 } & $\mathrm{G} 2$ & $\mathrm{G} 2.5$ & $\mathrm{G} 3$ \\
\hline TSI & $0.99 \pm 0.43$ & $1.56 \pm 0.84$ & $1.77 \pm 0.57^{\ddagger}$ \\
T1 & $1.26 \pm 0.50$ & $1.61 \pm 0.46$ & $2.19 \pm 0.47^{*}$ \\
T2 & $1.40 \pm 0.59$ & $1.82 \pm 0.58$ & $2.22 \pm 0.42^{*}$ \\
TFS & $1.51 \pm 0.73^{*}$ & $2.00 \pm 0.64^{*}$ & $2.56 \pm 0.69^{* *}$ \\
TEI & $1.42 \pm 0.59$ & $1.95 \pm 0.63^{*}$ & $2.37 \pm 0.58^{* \ddagger}$ \\
Time point & & Plasma M1 $(\mathrm{X} \pm \mathrm{S})$ & $1.08 \pm 0.58^{\ddagger}$ \\
TSI & $0.69 \pm 0.23$ & $1.02 \pm 0.45^{\ddagger}$ & $1.40 \pm 0.38^{*}$ \\
T1 & $0.89 \pm 0.38^{*}$ & $1.14 \pm 0.33$ & $1.43 \pm 0.36^{\ddagger}$ \\
T2 & $0.90 \pm 0.44$ & $1.21 \pm 0.41$ & $1.66 \pm 0.55^{* *}$ \\
TFS & $1.07 \pm 0.45^{*}$ & $1.39 \pm 0.49^{*}$ & $1.68 \pm 0.38^{* \ddagger}$ \\
TEI & $1.06 \pm 0.47^{*}$ & $1.36 \pm 0.49^{*}$ &
\end{tabular}

*Differs from baseline according to Tukey test $(\mathrm{P}<0.05)$. ${ }^{*}$ Differs from $\mathrm{G} 2$ according to Tukey test $(\mathrm{P}<0.05)$. Data transformed to log.

TSI - surgical incision, T1 - manipulation of the periosteum or joint, T2 - important times of nociceptive stimulation, TFS - final suture and TEI - end of tramadol infusion.

The ET $_{\text {ISO }}^{\prime}$, as well as blood gas variables, did not differ among groups or time points. Values ranged from $0.7 \%$ (one animal in $\mathrm{G} 2.5$ ) to $1.8 \%$ (one animal in G3) at TSI. The need for perioperative fentanyl was not related with group or type of surgery. Most cases where fentanyl was required belonged to G3 (four animals). In addition, tramadol analgesia was more effective in osteosyntheses using external fixation compared to other surgeries. Effective analgesia was defined as no requirement for additional analgesia in $85.7 \%$ of the subjects (6/7). On the other hand, osteosyntheses performed with medullary pins showed slightly less efficacy, as tramadol CRI sufficed for $71.4 \%$ animals (5/7). During knee joint surgeries and femoral head ostectomies, which involve the periosteum and the joint capsule, tramadol sufficed for $75 \%(6 / 8)$ and $62.5 \%(5 / 8)$ of the procedures, respectively.
Postoperative pain assessment using pain scales did not differ among groups with regard to mean time to rescue analgesia (Table.4). Individually, however, results were different. Six subjects required additional analgesia during the first 30 minutes of recovery from general anesthesia. These animals received rescue analgesia immediately and were excluded from further evaluations. Pain scales (Glasgow composite pain scale and Melbourne pain scale) were used in a total of 14 subjects and no correlation was found between duration of analgesia and score. Data are presented as medians, where $\mathrm{G} 2=30$; $62.5=60$; and $\mathrm{G} 3=60$ minutes. Postoperative analgesia was longer in two subjects, in which rescue analgesia was administered after 150 and 210 minutes (G3 and G2, respectively).

Table 4. Mean ( X ) \pm standard deviation (S) and median (Med) of time to rescue analgesia (minutes) of dogs subjected to tramadol infusion at $2(\mathrm{G} 2), 2.5(\mathrm{G} 2.5)$ or $3(\mathrm{G} 3) \mathrm{mg} \mathrm{kg}^{-1} \mathrm{~h}^{-1}$, following general anesthesia with isoflurane

\begin{tabular}{rccccc}
\hline \multicolumn{7}{c}{ Time to rescue analgesia (minutes) } \\
\hline G2 & \multicolumn{7}{c}{$\mathrm{G} 2.5$} & $\mathrm{G} 3$ \\
$(\mathrm{X} \pm \mathrm{S})$ & Med & $(\mathrm{X} \pm \mathrm{S})$ & Med & $(\mathrm{X} \pm \mathrm{S})$ & Med \\
$55.7 \pm 68.0$ & 30 & $54.0 \pm 25.1$ & 60 & $66.0 \pm 49.3$ & 60 \\
\hline
\end{tabular}

$\mathrm{G} 2=\mathrm{G} 2.5=\mathrm{G} 3$ Kruskal-Wallis test: $\mathrm{P}=0.3581$. 


\section{DISCUSSION}

Tramadol analgesia through continuous infusion at different rates was satisfactory in most subjects undergoing different types of orthopedic surgery. However, postoperative residual analgesia was short-lived and greater infusion rates plasma concentrations of tramadol and $\mathrm{O}$ desmethyltramadol were not associated with greater efficacy.

Tramadol given by CRI provided cardiovascular and respiratory stability in healthy dogs. Hypotension and respiratory depression were not observed in any subjects, corroborating other studies regarding the use of this agent by different routes and at different doses (Mastrocinque and Fantoni, 2003; Yazbek and Fantoni, 2005; McMillan et al., 2008; Vettorato et al., 2010). Paolozzi et al. (2011) have observed only a few cardiorespiratory changes that were not dose-related when using intravenous tramadol at 1,2 and $4 \mathrm{mg} \mathrm{kg}^{-1}$ in bitches undergoing ovariohysterectomy.

Tramadol is reportedly devoid of respiratory depression due to its weak interaction with opioid receptors. In addition, analgesia is potentiated by non-opioid mechanisms, which are not associated with cardiorespiratory changes (Ide et al., 2006) compared to other opiates (Karrasch et al., 2015).

The efficacy of analgesia with a given drug has been demonstrated in previous studies by physiological changes that indicate pain. Serum cortisol dosing was an interesting addition to this assessment in various studies, since this is a hormone that increases its levels during surgery and postoperative pain (Mastrocinque and Fantoni, 2003; Caldeira et al., 2006). Cortisol levels showed an increase over time during the postoperative period, which can be related to clearance of tramadol and onset of postoperative pain.

Albuquerque et al. (2015) have reported higher levels of cortisol during ovariohysterectomies at the time of vessel clamping when compared to physiological levels, corroborating another study by Paolozzi et al. (2011) and the present study. At T1, serum cortisol increased significantly, suggesting that tramadol, regardless of the rate of infusion, did not inhibit the stress response caused by surgical trauma. However, apart from the sensation of pain, cortisol levels can vary due to other factors, such as fear, anxiety, surgical time and environment (Fox et al., 1994; Vadivelu et al., 2014).

Many studies have shown that tramadol produces effective analgesia through different routes and at various doses in dogs undergoing ovariohysterectomy or orthopedic surgeries (Kukanich and Papich, 2004; Yazbek and Fantoni 2005; Vettorato et al., 2010). In this scenario, Benitez et al. (2015) compared the clinical efficacy of orally administered hydrocodone, acetaminophen and tramadol for postoperative pain management following tibial ostectomy in dogs and have not observed any differences among drugs.

In this study, perioperative analgesia provided by tramadol infusion sufficed for most procedures. No correlation was found, however, between the need for additional analgesia and the rate of tramadol infusion. This can be ascribed to the proximity of the rates used in this study $(0.5 \mathrm{mg}$ $\mathrm{kg}^{-1}$ range between groups), which might not evidence differences among groups.

This study investigated plasma concentrations of tramadol at different rates of continuous infusion. Plasma concentrations can vary according to dose, route of administration and species.

Giorgi et al. (2010) have reported a 92\% bioavailability and $80-125 \%$ bioequivalence of tramadol. After intramuscular administration, tramadol reached a peak of $2.52 \mu \mathrm{g} \mathrm{mL}^{-1}$ at 0.34 hours. There were no differences between IM and IV administration, and the effective plasma concentration was reached after a few minutes, lasting for 6 to 7 hours in both cases.

McMillan et al. (2008) have investigated the pharmacokinetics of IV tramadol and M1 in dogs and have reported short elimination half-life, which corroborates the findings of Kukanich and Papich (2004) of 1.28, 2.04 and 1.36 hours after tramadol administration at 1,2 and $4 \mathrm{mg} \mathrm{kg}^{-1}$, respectively. Those results are similar to the findings of this study, where plasma concentrations of tramadol and M1 were low, indicating rapid elimination. 
Longer elimination times were observed by Itami et al. (2016) when investigating the pharmacokinetics of intravenous tramadol. Values varied from 953.1 \pm 292.4 to $1702.3 \pm 439.6 \mathrm{mg} \mathrm{kg}^{-1}$ in young and middle-aged animals, respectively.

One study regarding the influence of genes on M1 formation has showed that low concentrations of M1 are associated with high levels of M2 and are mediated respectively by CYP2D15 and CYP2B11 / CYP3A12. Furthermore, Giorgi et al. (2010) have found low M1 concentrations and similar levels of other metabolites after both IV and IM administration.

Surgical planes of anesthesia are usually at 1.2 to 1.4 times the MAC, which are close to $1.69 \%$ of isoflurane in dogs (Figueiró et al., 2016). Vettorato et al. (2010) have observed values between 1.3 and $1.4 \%$ (approximately $1 \mathrm{MAC}$ ) at the start of surgery with tramadol analgesia, corroborating another study reporting lower

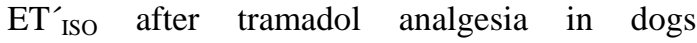
(Mastrocinque and Fantoni, 2003). It is worth noting that the type of pain (somatic vs. visceral pain) and surgery were different between these two studies and thus comparisons might not reflect real similarities.

The anesthetic requirement was not correlated with different rates of tramadol infusion in this study. The lowest and highest rates were respectively associated with reductions of $26 \pm 8 \%$ and $36 \pm 12 \%$ on the ET $^{\prime}{ }_{\text {ISO }}$. Although not statistically significant, the highest rate seemingly caused a greater reduction compared to the lowest rate of tramadol infusion.

Seddigh et al. (2009) have observed significant reduction on sevoflurane concentrations with CRI of tramadol at two rates: (1) $1.5 \mathrm{mg} \mathrm{kg} \mathrm{kg}^{-1}$ bolus followed by $1.3 \mathrm{mg} \mathrm{kg}^{-1} \mathrm{~h}^{-1}$; and (2) $3 \mathrm{mg}$ $\mathrm{kg}^{-1}$ bolus followed by $2.6 \mathrm{mg} \mathrm{kg}^{-1} \mathrm{~h}^{-1}$. Another study comparing a combination of tramadol and morphine to morphine alone has demonstrated a significant decrease in the end-tidal concentration of sevoflurane with the combined opioids (Mahidol et al., 2015).

Recognizing and quantifying pain still poses a challenge for many professionals (Vettorato et al., 2010). The ideal pain scale should be objective, reliable and easy to apply. In this study, two already validated scales were used and results were useful for pain recognition. Scales were not different in identifying the time to administer rescue analgesia. Six subjects needed additional analgesia shortly after recovery (30 to 60 minutes). This demonstrates the short duration of tramadol residual analgesia and warrants the need for postoperative analgesia following surgery with tramadol infusion.

The short period of residual analgesia can be explained by pharmacokinetic characteristics of tramadol. Studies investigating wider and more diversified populations are warranted in order to determine the true prevalence of M1 and whether tramadol analgesia is dose-dependent. This would then clarify possible metabolic differences that might interfere with the degree of analgesia, as seen in human populations.

In this study, adverse reactions such as excitation or vomiting were not observed even with the highest rate of infusion. Animals in G3 received a total of $10 \mathrm{mg} \mathrm{kg}^{-1}$ of tramadol, including premedication, bolus and the 2-hour CRI. A few studies report considerable incidence of vomiting even at low doses (Kukanich and Papich, 2004). Paolozzi et al. (2011) have observed vomiting in $50 \%$ of dogs that received intravenous tramadol at $4 \mathrm{mg} \mathrm{kg}^{-1}$, but none at 1 and $2 \mathrm{mg} \mathrm{kg}^{-1}$, which suggests that this effect might be related to higher doses. Other studies report low incidence or absence of adverse reactions to tramadol in dogs (Ide et al., 2006; Vettorato et al., 2010).

The findings of this study demonstrate the success of tramadol through continuous rate infusion for orthopedic procedures in dogs. However, due to the small number of subjects and the variability of nociceptive stimuli, additional studies using a higher number of subjects and standardized stimulation are required to effectively demonstrate the effects of tramadol for perioperative analgesia in dogs.

\section{CONCLUSIONS}

Constant rate infusion of tramadol at the studied rates produced adequate analgesia associated with cardiorespiratory stability and no adverse effects in most dogs undergoing orthopedic surgery. Analgesia was not dose-dependent, however, and postoperative residual effects were short-lived, which warrants proper postoperative analgesia following tramadol infusion. The lowest infusion rate can therefore be used for 
most orthopedic surgeries in dogs. This study is the first regarding continuous infusion of tramadol for perioperative analgesia in the canine species. Additional studies using higher rates of tramadol infusion and standardized nociceptive stimulation are required in order to determine to what degree doses influence tramadol analgesia and whether there is a limit to its effects in dogs.

\section{ACKNOWLEDGEMENTS}

The authors would like to thank the São Paulo Research Foundation (FAPESP, process no. 2011/03535-7) for funding this study and Professor Silvia Helena VenturoliPerri for the statistical analyses.

\section{REFERENCES}

ITAMI, T.; SAITO, Y.; ISHIZUKA, T. et al. Comparison of pharmacokinetics of tramadol between young and middle-aged dogs. J. Vet. Med. Sci., v.78, p.1031-1034, 2016.

ALBUQUERQUE, V.B.; ARAÚJO, M.A.; FERREIRA, G.T.N.M. et al. Epidural levobupivacaine alone or combined with different morphine doses in bitches under continuous propofol infusion. Arq. Bras. Med. Vet. Zootec., v.67, p.951-960, 2015.

BENITEZ, M.E.; ROUSH, J.K.; MCMURPHY, $\mathrm{R}$. et al. Clinical efficacy of hydrocodoneacetaminophen and tramadol for control of postoperative pain in dogs following tibial plateau leveling osteotomy. Am. J. Vet. Res., v.76, p.755-762, 2015.

CALDEIRA, F.M.C.; OLIVEIRA, P.H.; MELO, E.G. et al. Cortisol sérico e glicemia em cadelas tratadas com tramadol e submetidas à ováriohisterectomia. Ciênc. Rural, v.36, p.155-160, 2006.

FIGUEIRÓ, M.R.; SOARES, J.H.; ASCOLI, F.O. et al. Isoflurane MAC determination in dogs using three intensities of constant-current electrical stimulation. Vet. Anaesth. Analg., v.43, p.464-471, 2016.

FIRTH, A.M.; HALDANE,S.L. Development of a scale to evaluate postoperative pain in dogs. $J$. Am. Vet. Med. Assoc., v.1, p.214-215, 1999.
FOX, S.M.; MELLOR, D.J.; FIRTH, E.C. et al. Changes in plasma cortisol concentrations before, during and 66 after analgesia, anaesthesia plus ovariohysterectomy in bitches. Res. Vet. Sci., v.57, p.110-118, 1994.

GIORGI, M.; DEL CARLO, S.; ŁEBKOWSKAWIERUSZEWSKA, B. et al. Pharmacokinetics of tramadol and metabolites after injective administrations in dogs. J. Vet. Sci., v.13, p.639644, 2010.

IDE, S.; MINAMI, M.; ISHIHARA, K.; UHL, G.R. $\mathrm{Mu}$ opioid receptor-dependent and independent components in effects of tramadol. Neuropharmacology, v.51, p.651-658, 2006.

KARRASCH, N.M.; LERCHE, P.; AARNES, T.K. et al. The effects of preoperative oral administration of carprofen or tramadol on postoperative analgesia in dogs undergoing cutaneous tumor removal. Can. Vet. J., v.56, p.817-822, 2015.

KISSIN, I. Preemptive analgesia. Anesthesiology, v.93, p.1138-1143, 2000.

KUKANICH, B.; PAPICHK, M.G. Pharmacokinetics of tramadol and the metabolite O-desmethyltramadol in dogs. J. Vet. Pharmacol. Ther., v.27, p.239-246, 2004.

MAHIDOL, $\quad$ C.; $\quad$ NIYOM, S.; THITIYANAPORN, C. et al. Effects continuous intravenous infusion of morphine and morphinetramadol on the minimum alveolar concentration of sevoflurane and electroencephalographic entropy indices in dogs. Vet. Anaesth. Analg., v.42, p.182-186, 2015.

MASTROCINQUE, S.; $\quad$ FANTONI, D.T.Comparison of preoperative tramadol and morphine for control of early postoperative pain in bitches submitted to ovariohisterectomy. Vet. Anaesth. Analg., v.30, p.220-228, 2003.

McMILLAN, C.J.; LIVINGSTON, A.; CLARK, C.R. et al. Pharmacokinetics of intravenous tramadol in dogs. Can. Vet. J., v.72, p.325-331, 2008.

MORTON, C.M.; REID, J.; SCOTT, E.M. et al. Application of a scaling model to establish and validate and interval level pain scale for assessment of acute pain in dogs. Am. J. Vet. Res., v.66, p.2154-2166, 2005. 


\section{Oliva et al.}

PAOLOZZI, R.J.; CASSU, R.N.; CRUZ, F.S.F. et al. Diferentes doses de tramadol emcães: açõesanalgésicas, sedativas e sobre o sistemacardiorrespiratório. Ciênc. Rural, v.1, p.1417-1423, 2011.

SEDDIGH, M.R.; EGGER, C.M.; ROHRBACH, B.W. et al. Effects of tramadol on the minimum alveolar concentration of sevoflurane in dogs. Vet. Anaesth. Analg., v.36, p.334-340, 2009.

VADIVELU, N.; MITRA, S.; SCHERMER, E. et al. Preventive analgesia for postoperative pain control: a broader concept. Local. Reg. Anesth., v.29, p.17-22, 2014.
VETTORATO, E.; ZONCA, A.; ISOLA, M. et al. Pharmacokinetics and efficacy of intravenous and extradural tramadol in dogs. Vet. J., v.183, p.310-315, 2010.

YAZBEK, K.V.B.; FANTONI, D.T. Evaluation of tramadol, an "atypical" opiod analgesic in the control of immediate postoperative pain in dogs submitted to orthopedical surgical procedures. Braz. J. Vet. Res. Anim. Sci., v.42, p.250-258, 2005. 